ANNA BARCZAK ${ }^{*}$

Adrianna Ogonowska

\title{
DYNAMIKA PRAWA OCHRONY ŚRODOWISKA \\ A JEGO WYKEADNIA - \\ UWAGI NA TLE PRZEPISÓW U.C.P.G.
}

\section{Wstęp}

Gospodarka odpadami komunalnymi może być obecnie zaliczona do jednej z najbardziej dynamicznie rozwijających się materialnych części prawa ochrony środowiska. Przyczyn dynamicznego rozwoju przepisów dotyczących tego sektora jest wiele, tj. spełnienie wymagań unijnych i rozwijająca się przez to świadomość ustawodawcy wewnętrznego i organów samorządowych, coraz większa ingerencja człowieka w środowisko w postaci ilości wytwarzania odpadów komunalnych, coraz poważniejsze skutki tej ingerencji dla współczesnego i przyszłych pokoleń.

Tak dynamiczny rozwój przepisów w zakresie gospodarki odpadami komunalnymi powoduje, że ustawodawca, przeprowadzając liczne reformy $\mathrm{w}$ tej sferze, nie zawsze tworzy przepisy odpowiadające cechom dobrej legislacji ${ }^{1}$. Konstrukcja przepisów ustawy o utrzymaniu czystości i porządku $\mathrm{w}$ gminach ${ }^{2}$ narusza nie tylko reguły procesu legislacyjnego, wymagania dotyczące sposobu konstruowania przepisów, ale także zasady konstytucyjne. Wyżej wymieniona ustawa jest przykładem dość powszechnie już wskazywanego „kryzysu legislacyjnego”, chociaż jej rozwiązania z merytorycznego punktu widzenia idą we właściwą stronę.

* Dr hab., prof. Uniwersytetu Szczecińskiego; e-mail: anna.barczak@wpiaus.pl.

* Mgr, Uniwersytet Szczeciński; e-mail: adrianna.ogonowska@wpiaus.pl.

1 Zob. S. Wronkowska, Na czym polega dobra legislacja?, „Przegląd Legislacyjny” 2002, nr 1, s. 9-23.

2 Ustawa z dnia 13 września 1996 r. o utrzymaniu czystości i porządku w gminach, Dz. U. z 2017 r. poz. 1289 z późn. zm., tekst jednolity (dalej u.c.p.g.). 
W związku z powyższym, przedmiotem badań będzie zwrócenie uwagi na niektóre tylko wątpliwości związane ze stosowaniem przepisów u.c.p.g. Rozważaniom poddana zostanie przede wszystkim interpretacja tych regulacji, budzących obecnie najwięcej kontrowersji, a które weszły w życie w 2016 i 2017 r. Analizy nie sposób nie rozpocząć od prześledzenia ewolucji u.c.p.g., by następnie skupić się na wątpliwościach powstałych wokół pojęcia "odpadu komunalnego". Wiele zastrzeżeń pojawia się na tle nowych zasad selektywnej zbiórki odpadów komunalnych oraz zasad ustalania opłaty za gospodarowanie odpadami komunalnymi. Kontrowersje budzą także zamówienia in-house w ramach gospodarki odpadami komunalnymi.

\section{Rozwój przepisów w zakresie gospodarki odpadami komunalnymi na tle zmian u.c.p.g.}

Ustawa o utrzymaniu czystości i porządku w gminach weszła w życie 1 stycznia 1997 r. Jest to quasi-konstytucja gospodarki odpadami komunalnymi. W latach 1997-2018 akt ten był trzydzieści siedem razy nowelizowany (doczekał się aż pięciu tekstów jednolitych).

Do 2001 r. nowelizacje u.c.p.g. w zakresie gospodarki odpadami komunalnymi były niewielkie. Po tym okresie doszło do wielu zmian rewolucyjnych, które wielokrotnie zmieniały niemal wszystkie przepisy tejże ustawy. Pierwsza taka reforma została przeprowadzona w 2001 r. i miała ona charakter fundamentalny, albowiem zmieniono brzmienie wielu przepisów analizowanego aktu, bądź dodano nowe.

Kolejna reforma przepisów w zakresie gospodarki odpadami komunalnymi miała miejsce w 2005 r. Nowelizacja u.c.p.g. zmieniała bowiem niemal wszystkie przepisy merytoryczne ustawy. W istocie zmiany te miały głównie charakter porządkujący i uściślający, nie zmieniały koncepcji wypracowanej w latach 2001-2002 ${ }^{3}$. Podobnie w latach 2006-2011 nowelizacje u.c.p.g. miały głównie charakter porządkowy.

W dniu 1 lipca 2011 r. dokonana została gruntowna zmiana przepisów u.c.p.g. ${ }^{4}$ Na skutek tych przemian przeprowadzono następną i najważ-

3 Zob. W. Radecki, Utrzymanie czystości i porzadku w gminach. Komentarz, Warszawa 2012, s. 39. 
niejszą reformę gospodarki odpadami komunalnymi, określaną mianem rewolucyjnej. Ustawa nowelizująca wprowadziła przepisy przejściowe. W ostateczności rewolucja weszła w życie 1 lipca 2013 r. Ustawodawca zastrzegł jednak, że przepisy będą jeszcze nowelizowane, jeśli powstanie konieczność rozwiązania nasuwających się problemów. Reforma w zasadzie przemodelowała postępowanie $\mathrm{z}$ odpadami komunalnymi: zmieniła niemal wszystkie dotychczasowe przepisy u.c.p.g. (z wyj. art. $8 \mathrm{a}, 10$ i 14), dwa uchyliła (art. 8b i 9a), dodała 52 nowe przepisy (art. 1a, 3a-3c, 6c-6r, 9b-9z). Liczba artykułów u.c.p.g. z czternastu w tekście pierwotnym wzrosła do sześćdziesięciu - można zatem wskazać, że objętość ustawy zwiększyła się czterokrotnie (ustawodawca dodał pięć nowych rozdziałów).

Następne nowelizacje u.c.p.g. po 2013 r. doprecyzowują system, biorąc pod uwagę niedoskonałości rewolucji odpadowej, która zaczęła funkcjonować od 1 lipca $2013 \mathrm{r}$.

Z powyższej analizy wynika, że przepisy dotyczące gospodarki odpadami komunalnymi, regulowane przede wszystkim przez u.c.p.g., cechuje daleko idący dynamizm. Wydaje się, że gruntowne zmiany ustawy powinny być już zahamowane. Ustawodawca powinien dać możliwość funkcjonowania systemowi. Tak częste i fundamentalne zmiany powoduja, że adresaci nowelizowanych przepisów mają problemy z ich wdrażaniem.

$Z$ jednej strony staramy się mieć najlepsze w Europie uwarunkowania prawne, a z drugiej strony popieramy prace wykonywane niedbale i niefachowo, czego przykładem są liczne nowelizacje u.c.p.g. w zakresie postępowania z odpadami komunalnymi. Tak wiele zmian przyczyniło się do powstania wątpliwości przy zastosowaniu licznych norm prawnych. Zaradzeniu tej trudnej sytuacji służy wykładnia przepisów.

\section{Wątpliwości wokół pojęcia "odpadu komunalnego"}

Dynamiczny rozwój przepisów w zakresie regulacji dotyczących odpadów komunalnych, powoduje, że istnieje niejednoznaczność przyjmowanych definicji. Na uwagę zasługuje zwłaszcza pojęcie „odpadu

4 Ustawa z dnia 1 lipca 2011 r. o zmianie ustawy o utrzymaniu czystości i porządku w gminach oraz niektórych innych ustaw, Dz. U. z 2011 r. Nr 152, poz. 897 (dalej ustawa nowelizująca z 2011 r.). 
komunalnego". Mimo stworzenia definicji legalnej powyższego terminu, w praktyce zdarzały i zdarzają się problemy przy ustaleniu jego znaczenia. Słusznie $w$ piśmiennictwie zauważono, że jest to pojęcie zmienne zarówno w czasie, jak i w przestrzeni ${ }^{5}$. Termin ten bowiem zawsze dość skutecznie wymykał się spod kontroli językowej. Rozbieżności w pojmowaniu tego pojęcia prowadziły i prowadzą często do powstawania fałszywego obrazu stanu środowiska naturalnego, nieprawdziwych statystyk ilości odpadów wytworzonych, odzyskiwanych i składowanych ${ }^{6}$.

Do polskiego porządku prawnego definicja legalna "odpad komunalny" po raz pierwszy została wprowadzona dopiero w dniu 1 stycznia 1997 r. ${ }^{7}$ Na przełomie lat 1997-2017 definicja ta była modyfikowana sześciokrotnie $^{8}$. Zmiany te nie były do końca konsekwentne i budziły wątpliwości w praktyce. Analizując rozwiązania prawne należy zaznaczyć, że odpad komunalny zawsze był $\mathrm{i}$ jest przede wszystkim odpadem i stąd powinien spełniać cechy odpadu wynikające z jego definicji zawartej w ustawie o odpadach (zob. art. 3 ust. 1 pkt 7) ${ }^{9}$. To pozwala postawić tezę, że definicja odpadów komunalnych od początku jej istnienia nie miała charakteru autonomicznego. Musiała odwoływać się do pojęć wynikających z innych ustaw (tj. u.o. oraz u.c.p.g.). Takie stanowisko zostało również zaprezentowane $\mathrm{w}$ doktrynie ${ }^{10}$.

Istotne jest to, że pierwotnie (to jest do dnia 15 kwietnia 2000 r.) odpad komunalny mógł być jednocześnie odpadem niebezpiecznym. Od początku o uznaniu określonego odpadu za komunalny decydowało miejsce jego pochodzenia. Były to przede wszystkim odpady pochodzące z gospodarstw domowych, czyli odpady powstałe w wyniku normalnego funkcjonowania takiego gospodarstwa. Odpadem komunalnym były również odpady powstałe w obiektach użyteczności publicznej oraz obsługi

5 Zob. J. Jendrośka, J. Jerzmański (red.), Prawo ochrony środowiska dla praktyków, cz. 7, Warszawa 2006, s. 1.

6 Zob. M. Waksmańska, Projekt ramowej dyrektywy o odpadach, "Prawo i Środowisko” 2006, nr 1, s. 10-15.

7 W tym dniu weszła w życie u.c.p.g.

8 Szerzej zob. A. Barczak, Model gospodarowania odpadami komunalnymi w Polsce i Niemczech. Analiza prawnoporównawcza, Szczecin 2013, s. 38-40.

9 Ustawa z dnia 14 grudnia 2012 r. o odpadach, Dz. U. z 2016 r. poz. 1987, tekst jednolity (dalej u.o.).

10 Zob. W. Radecki, Ustawa o utrzymaniu czystości i porzadku w gminach z komentarzem, Wrocław 1997, s. 43. 
ludności, które zostały określone przez podanie przykładów. Wyszczególnienie tych przykładów budziło wątpliwości. W pierwszym komentarzu do u.c.p.g. W. Radecki wskazał, że „zdaje się nie ulegać wątpliwości, że do takich obiektów należą także teatry, kina, sklepy, zakłady gastronomiczne itp. Na tym tle może zrodzić się pytanie, czy na przykład odpadki ze stołówki zakładu przemysłowego są odpadami komunalnymi w rozumieniu art. 2 ust. 1 pkt 2 u.c.p.g. [wersja u.c.p.g. z 2000 r. - A.B.]? Należy przyjąć, że tak; one powinny być traktowane jak odpady z gospodarstw domowych, gdyż w istocie takimi sa, stołówka zakładowa jest bowiem jakimś odpowiednikiem gospodarstwa domowego" ${ }^{11}$.

Nowela z marca $2000 \mathrm{r}^{12}$ przyniosła istotne uzupełnienia i zmiany w definicji "odpadów komunalnych”. Nastąpiło rozszerzenie katalogu miejsc powstawania odpadów komunalnych o pomieszczenia użytkowe na cele biurowe lub socjalne. Nastąpiło także rozdzielenie odpadów komunalnych i niebezpiecznych (odpad niebezpieczny nigdy nie mógł być odpadem komunalnym). Wydaje się, że przyjęte założenie nie było do końca przemyślane, albowiem $\mathrm{w}$ praktyce $\mathrm{w}$ masie odpadów komunalnych zawsze były obecne odpady umieszczone na liście odpadów niebezpiecznych. Spowodowało to, że mieliśmy do czynienia z przepisem martwym.

Jak zauważył W. Radecki, istotę zmiany definicji „,odpadów komunalnych” dokonanej w 2000 r. można było sprowadzić do dwóch kwestii: „Po pierwsze, usunięto nonsensowną konsekwencję wynikającą z tekstu pierwotnego, nakazującą uznawanie za odpady inne niż komunalne odpadów powstających na przykład w stołówce zakładu przemysłowego czy w biurowcu takiego zakładu. Po drugie, z zakresu odpadów komunalnych wyeliminowano wszelkie odpady niebezpieczne; w stanie prawnym powstałym po wejściu w życie nowelizacji należało uznać, że odpad, który został wpisany na Listę odpadów niebezpiecznych, stanowiącą załącznik nr 2 do rozporządzenia MOŚZNiL z dnia 24 grudnia 1997 roku w sprawie klasyfikacji odpadów ${ }^{13}$, nigdy nie będzie odpadem komunalnym, choćby nawet został wytworzony $\mathrm{w}$ gospodarstwie domowym, obiekcie użyteczności

11 Tamże.

12 Ustawa z dnia 3 marca 2000 r. o zmianie ustawy o odpadach oraz o zmianie niektórych ustaw, Dz. U. z 2000 r. Nr 22, poz. 272.

13 Rozporządzenie Ministra Ochrony Środowiska, Zasobów Naturalnych i Leśnictwa z dnia 24 grudnia 1997 r. w sprawie klasyfikacji odpadów, Dz. U. z 1997 r. Nr 162, poz. 1135. 
publicznej i obsługi ludności, pomieszczeniu biurowym lub socjalnym albo odpadem ulicznym"14.

Z dniem 1 października 2001 r. wprowadzona została kolejna definicja odpadu komunalnego, która za podstawowe kryterium wyodrębnienia odpadu komunalnego uznała miejsce pochodzenia. Na jej podstawie odpad komunalny mógł być również odpadem niebezpiecznym, ale tylko w odniesieniu do odpadów powstających w gospodarstwach domowych. W odniesieniu do powstania odpadów poza gospodarstwem domowym, o ich uznaniu za odpady komunalne decyduje ocena podobieństwa (charakter lub skład) oraz jednoczesny brak wystąpienia odpadów niebezpiecznych. Wydaje się, że ocena taka przynajmniej w części powinna być oceną subiektywną. Dokonuje jej pierwszy posiadacz odpadu, czyli wytwórca. Idąc dalej, należy wskazać, że istnienie cech odpadu komunalnego ustala się zawsze z punktu widzenia momentu powstania odpadu ${ }^{15}$.

Reasumując, należy przychylić się do poglądu W. Radeckiego, który uważa, że „wyodrębniając odpady komunalne z kategorii odpadów «W ogóle» ustawodawca posłużył się dwoma kryteriami: miejscem pochodzenia odpadów, jakim jest gospodarstwo domowe, którego nie zdefiniował odrębnie, i słusznie, ponieważ jest to pojęcie potoczne, które należy rozumieć tak, jak się je normalnie w języku polskim rozumie oraz podobieństwem, co dotyczy odpadów powstających poza gospodarstwami domowymi - są one uznawane za odpady komunalne, jeżeli ze względu na swój charakter lub skład są podobne do odpadów powstających w gospodarstwach domowych"16.

14 W. Radecki, Ustawa o utrzymaniu czystości i porządku w gminach. Komentarz, Warszawa 2008, s. 68 .

15 Zob. J. Jendrośka, J. Jerzmański (red.), Prawo ochrony środowiska, cz. 7, s. 15.

16 W. Radecki, Utrzymanie czystości i porzadku w gminach. Komentarz, Warszawa 2005, s. 58 .

Kwestia rozumienia tego terminu była przedmiotem orzecznictwa Sądu Najwyższego (uchwała SN z dnia 24 stycznia 1996 r., III CZP 192/95, OSNC 1996, nr 6, poz. 77) na tle nieobowiązującego już dziś rozporządzenia Rady Ministrów z dnia 23 grudnia 1986 r. w sprawie urządzeń zaopatrzenia w wodę i urządzeń kanalizacyjnych oraz opłat za wodę i wprowadzanie ścieków (Dz. U Nr 47, poz. 234 ze zm.). Sąd uznał, że pojęcie „gospodarstwa domowego" - w rozumieniu tego rozporządzenia - nie obejmuje przypadków pobierania wody na budowę domu mieszkalnego i odprowadzania ścieków z takiej budowy. Zdaniem SN, interpretacja tego pojęcia powinna być restrykcyjna (ścisła). Kategoria gospodarstwa domowego znajduje zastosowanie w dziedzinie badań konsumpcji, a ta z natury rzeczy nie obejmuje, a nawet jest przeciwstawna (pojęciowo) działalności inwestorskiej 
Jak podkreśla dalej W. Radecki ${ }^{17}$, dodatkowym kryterium klasyfikacyjnym jest cecha niebezpieczności odpadów. Jej sens wyraża się w tym, że w odpadach powstających w gospodarstwach domowych mogą znajdować się odpady niebezpieczne, co nie sprawia, że odpady zmieniają swój charakter prawny - są one nadal odpadami komunalnymi. Inaczej jest natomiast w odniesieniu do odpadów powstających poza gospodarstwami domowymi, albowiem jeżeli zawierają one odpady niebezpieczne, to już nie są odpadami komunalnymi.

\section{Wątpliwości wokół selektywnej zbiórki odpadów}

Ustanawianie selektywnego zbierania odpadów komunalnych, które obejmują co najmniej następujące frakcje odpadów: papieru, metalu, tworzywa sztuczne, szkła i opakowań wielomateriałowych oraz odpadów komunalnych ulegających biodegradacji, w tym odpadów opakowaniowych ulegających biodegradacji (art. 3 ust. 2 pkt 5 u.c.p.g.), należy do obowiązkowych zadań własnych gminy.

Artykuł 3 ust. 1 pkt 24 u.o. zawiera definicję selektywnego zbierania odpadów. Zgodnie z cytowanym powyżej przepisem przez selektywne zbieranie rozumie się zbieranie, $\mathrm{w}$ ramach którego dany strumień odpadów, w celu ułatwienia specyficznego przetwarzania, obejmuje jedynie rodzaje odpadów charakteryzujące się takimi samymi właściwościami i takim samymi cechami. W przypadku selektywnie zebranych odpadów komunalnych obowiązuje zakaz ich mieszania ze zmieszanymi odpadami komunalnymi odbieranymi od właścicieli nieruchomości. Definicja powyższa ma transponować definicję z dyrektywy ramowej 2008/98 ${ }^{18}$, gdzie jednak zawarto określenie bardziej ogólne, albowiem - zgodnie z art. 3

(produkcyjnej), polegającej na tworzeniu nowych dóbr, także konsumpcyjnych, bo do takich należy dom mieszkalny. Przyjęcie założenia, że pojęcie "gospodarstwo domowe" wiąże się z konsumpcją a nie produkcja, może być wskazówką w odniesieniu do pochodzenia odpadów komunalnych. Taki pogląd zaprezentował W. Radecki, zob. W. Radecki, Ustawa o utrzymaniu czystości i porządku w gminach. Komentarz, Warszawa 2008, s. 73.

17 Zob. tamże.

18 Dyrektywa Parlamentu Europejskiego i Rady 2008/98/WE z dnia 19 listopada 2008 r. w sprawie odpadów oraz uchylająca niektóre dyrektywy, Dz. Urz. UE z 22.11.2008, L. 312 , s. 3. 
pkt 11 wskazanej dyrektywy - „selektywna zbiórka oznacza zbiórkę, w ramach której dany strumień odpadów obejmuje jedynie odpady jednego rodzaju i o tym samym charakterze, w celu ułatwienia specyficznego przetwarzania". Jak słusznie zauważa M. Górski, w tej definicji nie ma odwołania do właściwości danego rodzaju odpadów, a pod tym pojęciem chyba należałoby rozumieć właściwości fizyczne i chemiczne. W konsekwencji użycie tego pojęcia bardzo zawęża możliwości uznania, że dany strumień odpadów został zebrany selektywnie, jeżeli musiałyby mieć one takie same właściwości ${ }^{19}$.

Zgodnie $z$ art. 3 ust. 2 pkt 5 u.c.p.g. selektywne zbieranie ustanawiają gminy, co oznacza, że gminy zorganizują takie selektywne zbieranie lub stworzą konieczne do tego warunki.

Selektywne zbieranie powyższych frakcji jest między innymi powiązane z koniecznością osiagnnięcia przez gminy wymaganych poziomów recyklingu i przygotowania do ponownego użycia papieru, metali, tworzyw sztucznych i szkła (art. $3 b$ ust. 1 pkt 1 u.c.p.g.) oraz ograniczenia masy odpadów komunalnych ulegających biodegradacji (art. 3c ust. 1 u.c.p.g.).

Skonstruowanie systemów selektywnej zbiórki odpadów komunalnych, od strony formalnoprawnej, gminy powinny uczynić poprzez skonstruowanie odpowiednich wymagań $\mathrm{w}$ regulaminie oraz $\mathrm{w}$ uchwale rady gminy, podjętej na podstawie art. 6r ust. 3 u.c.p.g.

Dnia 1 lipca 2017 r. weszło w życie rozporządzenie Ministra Środowiska z dnia 29 grudnia 2016 r. w sprawie szczegółowego sposobu selektywnego zbierania wybranych frakcji odpadów ${ }^{20}$. Tym samym została wprowadzona przez niego „mała rewolucja” w zakresie gospodarki odpadów komunalnych. Akt ten nie jest zbyt obszerny (liczy siedem paragrafów), ale materia, którą w nim unormowano, wywołuje liczne wątpliwości u jego adresatów (tj. gmin), w szczególności dotyczące przepisów intertemporalnych rozporządzenia. Ponad to nie wszystkie gminy obecnie mają tak zorganizowany system selektywnej zbiórki odpadów, jak to wynika z rozporządzenia. Gminom nie pozostawiono zatem wyboru, muszą dostosować się do zasad wynikających $\mathrm{z}$ nowego rozporządzenia, w tym powinny zmienić regulaminy utrzymania czystości i porządku na terenie

19 Zob. M. Górski, Organizacja selektywnej zbiórki odpadów, „Przegląd Komunalny” 2012, nr 5, s. 23.

20 Rozporządzenie Ministra Środowiska z dnia 29 grudnia 2016 r. w sprawie szczegółowego sposobu selektywnego zbierania wybranych frakcji odpadów, Dz. U. z 2017 r. poz. 19. 
gminy. W związku z powyższym gminy oraz podmioty odbierające albo odbierające i zagospodarowujące odpady komunalne mają wiele wątpliwości, czy i jaki wpływ będzie miało powyższe rozporządzenie na dotychczas obowiązujące umowy niedostosowane do rozporządzenia ${ }^{21}$.

W związku z licznymi pytaniami, które zrodziły się na tle nowego rozporządzenia, Ministerstwo Środowiska w dniu 5 kwietnia 2017 r. udzieliło odpowiedzi na interpelację poselska, pismem o sygnaturze DGO-III.070.15.2017.MK²2. W swoich wyjaśnieniach ministerstwo poświęciło najwięcej uwagi przepisom przejściowym, wyjaśniając tym samym niepewności interpretacyjne ${ }^{23}$.

Rozporządzenie nie precyzuje rodzajów odpadów objętych zbiórką w ramach danego strumienia. Szczególnie niejasno sformułowane są wymagania w zakresie zbiórki bioodpadów w pojemniku brązowym. Zakres frakcji odpadów objętych zbiórką został określony w wytycznych opublikowanych na stronie internetowej Ministerstwa Środowiska ${ }^{24}$. Rozporządzenie weszło w życie 1 lipca 2017 r., jednak w przypadku wcześniej zawartych umów na odbieranie odpadów, zachowują one ważność przez okres nie dłuższy niż 4 lata. Ponadto gminy mają 5 lat na dostosowanie pojemników do nowych wymogów.

Analiza niektórych umów zawieranych w trybie przetargów nieograniczonych pozwala stwierdzić, że nie przewidziano w nich regulacji zobowiązujących przedsiębiorców do zmian w systemie odbioru lub odbioru i zagospodarowania odpadów komunalnych w przypadku nowelizacji przepisów prawnych ${ }^{25}$.

Ponadto wątpliwości interpretacyjne budzi sposób oznaczenia worków stosowanych w selektywnej zbiórce odpadów. Ma to miejsce w sytuacji, gdy niektóre gminy odbierały od swoich mieszkańców frakcje zarówno objęte rozporządzeniem, jak i frakcje nieobjęte rozporządzeniem,

${ }^{21}$ Zob. I. Romańczuk, M. Rzewnicka, Ustawa o utrzymaniu czystości i porządku w gminach. Komentarz, Warszawa 2017, s. 65.

${ }^{22}$ http://orka2.sejm.gov.pl/INT8.msf/klucz/658C47EE/\%24FILE/i10708-ol.pdf [dostęp: 5.01.2018 r.].

23 Zob. P. Michalski, Nowe zasady selektywnej zbiórki odpadów, "Gazeta Samorządu i Administracji” 2017, nr 6, s. 25-27; B. Draniewicz, Mała rewolucja śmieciowa w interpretacji Ministerstwa Środowiska, „Prawo i Środowisko” 2017, nr 2, s. 105-112.

24 Ministerstwo Środowiska, ABC Segregacji odpadów, htpps://www.mos.gov.pl/aktualności/szegoly/news/abc-segregacji-odadow/ [dostęp: 20.12.2017 r.].

25 Zob. I. Romańczuk, M. Rzewnicka, Ustawa o utrzymaniu czystości, s. 65. 
np. popioły z palenisk domowych. W niektórych gminach frakcja nieobjęta rozporządzeniem jest zbierana w workach w kolorze brązowym.

Kontrowersje budzi także pytanie o sposób zbierania odpadów ulegających biodegradacji - czy istnieje możliwość oddzielnego zbierania odpadów zielonych, czy obowiązek łącznego zbierania wszystkich odpadów ulegających biodegradacji, tj. także tzw. odpadów kuchennych. Ministerstwo Środowiska wskazało, że gmina decyduje o tym, czy będzie zbierała odpady zielone łącznie z odpadami kuchennymi, czy też określi oddzielny sposób ich zbierania. Gmina zatem powinna przyjąć w regulaminie utrzymania czystości i porządku sposób, w jaki powinny być zbierane odpady zielone.

\section{Wykładnia zasad ustalania opłaty $\mathrm{w}$ zakresie gospodarowania odpadami komunalnymi}

Obecnie obowiązujący system opłat $\mathrm{w}$ zakresie gospodarowania odpadami komunalnymi, wprowadzony przepisami u.c.p.g., cechuje zróżnicowanie przede wszystkim pod względem zasad ustalania takich opłat. Podstawę poniższych rozważań stanowi przeprowadzenie wykładni przepisów art. 6, art. 6c ust. 1 i 2 oraz art. 6j u.c.p.g. W rezultacie należy wyróżnić trzy potencjalne sytuacje stanowiące podstawę wskazanego zróżnicowania:

- opłatę uiszcza właściciel nieruchomości, na której zamieszkują mieszkańcy,

- opłatę uiszcza właściciel nieruchomości, na której nie zamieszkują mieszkańcy, a powstają odpady komunalne, gdy rada gminy podjęła uchwałę o objęciu takiej nieruchomości systemem gminnym,

- opłatę uiszcza właściciel nieruchomości, na której nie zamieszkują mieszkańcy, a powstają odpady komunalne, gdy rada gminy nie podjęła uchwały o objęciu takiej nieruchomości systemem gminnym.

W pierwszej z wymienionych sytuacji opłata przyjmuje nazwę opłaty za gospodarowanie odpadami komunalnymi. Należy zwrócić uwagę, że opłata uiszczana przez właściciela nieruchomości zamieszkałej przez mieszkańców stanowi iloczyn stawki opłaty oraz jednej z trzech metod ustalenia opłaty za gospodarowanie odpadami komunalnymi (liczby mieszkańców zamieszkujących daną nieruchomość, ilości zużytej wody z danej nieruchomości albo powierzchni lokalu mieszkalnego). Wskazać należy, że zarówno 
stawka opłaty ${ }^{26}$, jak i metoda ustalenia opłaty za gospodarowanie odpadami komunalnymi wybierana jest przez radę gminy $\mathrm{w}$ drodze stosownej uchwały ${ }^{27}$. Warto zaakcentować również istnienie dodatkowej metody ustalenia opłaty za gospodarowanie odpadami komunalnymi, zgodnie z którą rada gminy może uchwalić jedną stawkę opłaty od gospodarstwa domowego. Co istotne, na obszarze jednej gminy dopuszczalne jest stosowanie więcej niż jednej metody ustalenia analizowanej opłaty. Warto zasygnalizować, że w literaturze przedmiotu krytycznie oceniony został brak jednej uniwersalnej metody pozwalającej na proporcjonalne finansowanie przez wytwórców odpadów kosztów gospodarowania nimi ${ }^{28}$.

W drugiej z wymienionych sytuacji, gdy opłata uiszczana jest przez właściciela nieruchomości, na której nie zamieszkują mieszkańcy, a powstają odpady komunalne, kluczową kwestią jest objęcie nieruchomości systemem gminnym na mocy uchwały będącej aktem prawa miejscowego,

26 Warto zaznaczyć, że na gruncie polskiego porządku prawnego określono kryteria, do których wzięcia pod uwagę rada gminy została zobowiązana podczas ustalania wysokości stawki opłaty za gospodarowanie odpadami komunalnymi. Zalicza się do nich: liczbę mieszkańców zamieszkujących daną gminę, ilość wytwarzanych na terenie gminy odpadów komunalnych, koszty funkcjonowania systemu gospodarowania odpadami komunalnymi oraz przypadki, w których właściciele nieruchomości wytwarzają odpady nieregularnie (sezonowo). Jednocześnie, rada gminy została upoważniona do zróżnicowania stawki opłaty w zależności od powierzchni lokalu mieszkalnego, liczby mieszkańców zamieszkujących nieruchomość, odbierania odpadów z terenów wiejskich lub miejskich, a także od rodzaju zabudowy. Należy wskazać, że ustawodawca określił również maksymalne stawki opłat za zbieranie i odbieranie odpadów komunalnych w sposób selektywny oraz zobowiązał gminy do określenia wyższych stawek opłaty za gospodarowanie odpadami komunalnymi, jeżeli odpady komunalne nie są w taki sposób zbierane i odbierane, zob. M. Ofiarska, Z. Ofiarski, Finansowe podstawy systemu gospodarowania odpadami komunalnymi, [w:] M. Górski, K. Nowacki (red.), Prawne i organizacyjne obowiazki gmin w postępowaniu z odpadami komunalnymi, Wrocław 2012, s. 196-198; Z. Bukowski, Prawo gospodarki odpadami, Poznań 2014, s. 148. Warto dodać, że u.c.p.g. w sposób bezpośredni stawia w lepszej sytuacji rodziny wielodzietne oraz gospodarstwa domowe, w których dochód nie przekracza kwoty uprawniającej do świadczeń pieniężnych z pomocy społecznej, przyznając radzie gminy upoważnienie do zwolnienia tych podmiotów z obowiązku uiszczania analizowanej opłaty nawet w całości.

27 Art. 6k ust. 1 u.c.p.g.; zob. W. Radecki, Utrzymanie czystości i porządku w gminach. Komentarz, Warszawa 2016, s. 266-273; B. Dziadkiewicz, Zasady gospodarki odpadami komunalnymi. Poradnik ze wzorami dokumentów, Warszawa 2011, s. 73-79.

28 Zob. A. Barczak, E. Kowalewska, Optata za gospodarowanie odpadami komunalnymi, „Acta Iuris Stetinensis” 2014, nr 835, s. 32-33; E. Górnicki, Dwa światy - dwa modele - jedna optata, „Przegląd Komunalny” 2012, nr 10, s. 56. 
o której mowa w art. 6c ust. 2 u.c.p.g. W tym przypadku opłata również nosi nazwę opłaty za gospodarowanie odpadami komunalnymi i stanowi iloczyn zadeklarowanej liczby pojemników z odpadami komunalnymi powstającymi na danej nieruchomości oraz stawki opłaty za pojemnik o określonej pojemności ustalonej przez radę gminy w drodze uchwały.

Należy zasygnalizować, że odmienne zasady ustalania opłaty obowiązują dla nieruchomości, na których świadczone są usługi hotelarskie, nieruchomości, na których znajdują się domki letniskowe lub wykorzystywane są na cele rekreacyjno-wypoczynkowe jedynie przez część roku oraz nieruchomości, których jedynie część jest zamieszkana przez mieszkańców. W pierwszym z wymienionych przypadków dopuszczalne jest, aby opłata za gospodarowanie odpadami komunalnymi stanowiła iloczyn ilości zużytej wody z danej nieruchomości oraz stawki ustalonej przez radę gminy. $\mathrm{W}$ drugim $\mathrm{z}$ wymienionych przypadków rada gminy została zobowiązana do uchwalenia ryczałtowej stawki opłaty za gospodarowanie odpadami komunalnymi za rok od domku letniskowego lub od innej nieruchomości wykorzystywanej na cele rekreacyjno-wypoczynkowe. Z kolei w przypadku nieruchomości mieszanych, co do zasady, sumuje się opłaty obliczone odrębnie dla nieruchomości zamieszkałej i niezamieszkałej, ale rada gminy została upoważniona do podjęcia uchwały ustalającej jeden z trzech sposobów ustalenia opłaty: wybór jednej z trzech metod właściwych dla nieruchomości zamieszkałych przez mieszkańców, przyjęcie jednej stawki dla gospodarstwa domowego albo obliczenie liczby pojemników, przy założeniu, że dla części nieruchomości, na której jest prowadzona działalność, uwzględnia się powierzchnię użytkową lokalu.

Podsumowując należy stwierdzić, że w dwóch powyższych sytuacjach mamy do czynienia z opłatą za gospodarowanie odpadami komunalnymi. Jest to należność publicznoprawna, która stanowi dochód gminy lub dochód związku międzygminnego w całości lub w części odpowiednio do zakresu przejętych zadań. Należy również wskazać, że pomimo charakteru ekwiwalentności za wykonane czynności, nie stanowi ona ceny za świadczenie usługi ${ }^{29}$.

W trzeciej z przedstawionych sytuacji, gdy opłatę uiszcza właściciel nieruchomości, na której nie zamieszkują mieszkańcy, a powstają odpady komunalne (przy założeniu, że rada gminy nie podjęła uchwały o objęciu takiej nieruchomości systemem gminnym), opłata ustalana jest w drodze

29 Zob. A. Barczak, E. Kowalewska, Optata za gospodarowanie odpadami komunalnymi, s. 41. 
umowy albo w drodze decyzji administracyjnej. Pierwszy z wariantów jest związany z korzystaniem z usług odbierania odpadów komunalnych na podstawie umowy zawieranej z gminną jednostką organizacyjną lub przedsiębiorcą wpisanym do rejestru działalności regulowanej. W tej sytuacji opłata nazywana jest opłatą za usługi odbierania odpadów komunalnych i ustanawia ją podmiot odbierający odpady komunalne ${ }^{30}$. Rola rady gminy ogranicza się do określenia górnych oraz różnicowania stawek opłat ponoszonych przez właścicieli nieruchomości za wymienione wyżej usługi. Należy zaznaczyć, że opłata może być ustalana również w drodze decyzji administracyjnej wydawanej z urzędu, co ma miejsce w sytuacji niezawarcia przez właścicieli nieruchomości umów na odbiór odpadów komunalnych. Wtedy opłata nazywana jest opłatą za odbieranie odpadów komunalnych, a decyzję administracyjna, o której mowa w zdaniu poprzednim wydaje wójt, burmistrz albo prezydent miasta ${ }^{31}$.

\section{Zamówienia in-house a gospodarka odpadami komunalnymi}

Od 1 stycznia 2017 r. ${ }^{32}$ obowiązują znowelizowane przepisy ustawy z dnia 29 stycznia 2004 r. Prawo zamówień publicznych ${ }^{33}$ oraz u.c.p.g. Wprowadziły one możliwość stosowania w gospodarce odpadami komunalnymi tzw. zamówień in-house (zamówień wewnętrznych). Wskazane zamówienia stanowią jedną z form współpracy publiczno-publicznej, występującą między instytucjami zamawiającymi a jednostkami ściśle od instytucji zamawiających uzależnionymi pod względem organizacyjnym i gospodarczym ${ }^{34}$.

30 Zob. A. Barczak, E. Kowalewska, Opłaty w zakresie gospodarowania odpadami komunalnymi, „Przegląd Podatków Lokalnych i Finansów Samorządowych” 2014, nr 5, s. 20-23.

31 A. Barczak, E. Kowalewska, Opłaty w zakresie gospodarowania odpadami komunalnymi, s. 20-23.

32 Ustawa z dnia 22 czerwca 2016 r. o zmianie ustawy - Prawo zamówień publicznych oraz niektórych innych ustaw, Dz. U. z 2016 r. poz. 1020.

33 Ustawa z dnia 29 stycznia 2004 r. Prawo zamówień publicznych, Dz. U. z 2017 r. poz.1579 z późn. zm., tekst jednolity (dalej Prawo zamówień publicznych).

34 Opinia prawna Urzędu Zamówień Publicznych nt. in-house, Wspótpraca publiczno-publiczna w rozumieniu ustawy Prawo zamówień publicznych, http://odpady.net.pl/2017/06/05/ opinia-prawna-uzp-nt-in-in-house/ [dostęp: 9.01.2017 r.]. 
Z punktu widzenia gospodarki odpadami komunalnymi zasygnalizowania wymaga obowiązek udzielania zamówień publicznych (w tym możliwość udzielania zamówień spółkom publicznym bez konieczności prowadzenia przetargu) oraz obowiązek zorganizowania przetargu dla nieruchomości niezamieszkałych.

W pierwszej kolejności należy zwrócić uwagę na uchylenie art. 3a u.c.p.g. (zadania gminy związane $\mathrm{z}$ budowa, utrzymaniem i eksploatacją regionalnych instalacji do przetwarzania odpadów komunalnych) oraz art. 6e u.c.p.g. (udział spółek z udziałem gminnym w przetargach organizowanych przez gminy), które było konieczne dla zapewnienia nowego kształtu systemu gospodarowania odpadami komunalnymi. Na gruncie obecnie obowiązującego prawa na gminie (wójcie, burmistrzu, prezydencie miasta) ciąży obowiązek udzielenia zamówienia publicznego na odbieranie odpadów komunalnych (albo zamówienia publicznego na odbieranie i zagospodarowanie tych odpadów) zarówno od właścicieli nieruchomości zamieszkałych, jak i niezamieszkałych przez mieszkańców. Należy zaznaczyć, że nie wprowadzono w tym przypadku ograniczenia do określonych trybów udzielania zamówień (np. do przetargów nieograniczonych lub ograniczonych) ${ }^{35}$. W konsekwencji zamówienie może być udzielone również z wolnej ręki w ramach in-house, co zależy wyłącznie od spełnienia przesłanek uzasadniających zastosowanie trybu niekonkurencyjnego określonych $\mathrm{w}$ art. 67 ust. 1 pkt 12-15 Prawa zamówień publicznych ${ }^{36}$. W tym przypadku przesłanki uprawniające do zastosowania trybu z wolnej ręki powinny być interpretowane ściśle jako wyjątek od zasady udzielania zamówień w trybach podstawowych, dlatego na zamawiającym spoczywa obowiązek wykazania ich istnienia ${ }^{37}$.

Zwrócenia szczególnej uwagi wymaga również obowiązek gminy $\mathrm{w}$ postaci zorganizowania przetargu ograniczonego lub nieograniczonego na odbiór (albo odbiór i zagospodarowanie odpadów komunalnych) od właścicieli nieruchomości niezamieszkanych przez mieszkańców, ale objętych systemem gminnym. W tym przypadku niedopuszczalne jest zastosowanie innych trybów udzielenia zamówienia publicznego. Niektóre

35 Zob. R. Cieślak, Jak zamówienia in-house usprawnia gospodarkę odpadami, „Gazeta Samorządu i Administracji" 2017, nr 4, s. 17-18.

${ }^{36}$ Zob. F. Poniewski, Zamówienia in house w gospodarce odpadami, "Gazeta Samorządu i Administracji 2016, nr 10, s. 11-13.

37 Wyrok Krajowej Izby Odwoławczej z dnia 3 marca 2017 r., KIO 328/17, LEGALIS nr 1580875. 
kwestie zostały jednak przez ustawodawcę pominięte. Przykładowo w znowelizowanym brzmieniu u.c.p.g. krytycznie oceniany jest brak uregulowań dotyczących nieruchomości, jedynie częściowo, zamieszkanych przez mieszkańców ${ }^{38}$.

\section{Podsumowanie}

Ustawa o utrzymaniu czystości i porządku w gminach była wielokrotnie nowelizowana. $W$ doktrynie niektóre jej zmiany nazywane były rewolucyjnymi. Mimo tych istotnych zmian ustawodawca zastrzegł sobie kolejne nowelizacje, co czyni konsekwentnie. To powoduje, że jej przepisy częściowo stały się nieczytelne. Wątpliwości, wymagające interpretacji przepisów, dotyczą między innymi pojęcia „odpad komunalny”. Analiza regulacji prawnych pozwala stwierdzić, że termin ten przechodził swoje ewolucje na przestrzeni lat. Te zmiany przyczyniły się do tego, że termin ten nie powinien być już modyfikowany. Jego obecne brzmienie nie powinno budzić większych wątpliwości, z wyjątkiem zastrzeżeń, które zostały przedstawione powyżej.

Trudności interpretacyjne powstały w wyniku ostatnich zmian u.c.p.g. oraz ustawy Prawo zamówień publicznych. Kluczowe znaczenie ma „mała rewolucja” dotycząca selektywnego zbierania wybranych frakcji odpadów. Nowelizacja ta została wprowadzona rozporządzeniem Ministra Środowiska. W wyniku tego aktu prawnego ustanowiono jednakowe zasady selektywnej zbiórki odpadów komunalnych i nowy model selektywnego zbierania odpadów „u źródła” w podziale na odpowiednie frakcje. Adresaci rozporządzenia mają wiele problemów, które dotyczą zarówno nowych zasad zbierania odpadów, jak i stosowania u.c.p.g. w praktyce. Wątpliwości związane są głównie ze sporządzaniem prawidłowych regulaminów utrzymania czystości i porządku w gminie, dotyczą one także sprawozdawczości czy zawierania umów na odbieranie odpadów komunalnych od właścicieli nieruchomości.

Pewne problemy interpretacyjne związane są także z systemem opłat w zakresie gospodarowania odpadami komunalnymi. System ten cechuje zróżnicowanie zasad ustalania takich opłat. Biorąc pod uwagę powyższe

38 Zob. R. Cieślak, Jak zamówienia in-house usprawnia gospodarkę odpadami, s. 17-18. 
rozważania należy wskazać, że opłatami w zakresie gospodarowania odpadami komunalnymi są: opłata za gospodarowanie odpadami komunalnymi, opłata za usługi odbierania odpadów komunalnych oraz opłata za odbieranie odpadów komunalnych. Pierwsza z nich ustalana jest przez radę gminy, druga przez odbierającego odpady komunalne (z uwzględnieniem górnych stawek opłat), a trzecia przez wójta, burmistrza albo prezydenta miasta. W rezultacie stwierdzić należy, że dynamiczny rozwój przepisów prawnych w niniejszym zakresie doprowadził to wykreowania dużej liczby rozwiązań prawnych, które jednak nie zostały dostatecznie zintegrowane i ujednolicone. Krytycznie ocenić należy to, że występują aż trzy rodzaje opłat w zakresie gospodarowania odpadami komunalnymi, a ponadto każdą z nich można ustalać na kilka sposobów. Jeżeli ustawodawca nie uznaje za racjonalne wprowadzenie tylko jednego rodzaju opłaty, powinien chociażby rozważyć wprowadzenie jednej uniwersalistycznej metody jej ustalania.

Zmiana ustawy Prawo zamówień publicznych, która weszła w życie 1 stycznia 2017 r. złagodziła reżim stosowania przetargów w trybie powyższej ustawy. Wprowadzono możliwość udzielenia zamówienia publicznego z wolnej ręki (in-house). W rezultacie gminy zostały wyposażone w praktycznie nieograniczoną samodzielność wyboru podmiotów odbierających odpady komunalne (z wyjątkiem wyboru podmiotów odbierających odpady komunalne od nieruchomości niezamieszkanych przez mieszkańców, ale objętych systemem gminnym). Na krytykę zasługuje dopuszczona prawem możliwość udzielania zamówień in-house praktycznie w każdej z możliwych sytuacji, która w rezultacie nadmiernie promuje tryby niekonkurencyjne. Ponadto, wątpliwości budzi kwestia pominięcia uregulowania sytuacji właścicieli nieruchomości mieszanych podczas określania wyboru podmiotu odpowiedzialnego za odbieranie od nich odpadów komunalnych. Dynamiczny rozwój przepisów w zakresie gospodarki odpadami komunalnymi powinien przyczyniać się do poprawy zupełności i kompleksowości systemu prawnego, co w tej sytuacji jednak nie występuje.

Słowa kluczowe: wykładnia, odpady komunalne, selektywna zbiórka odpadów, zamówienia in-house, opłaty w zakresie gospodarowania odpadami komunalnymi 


\section{Bibliografia}

\section{ŹRÓDŁA}

\section{Akty prawne}

Dyrektywa Parlamentu Europejskiego i Rady 2008/98/WE z dnia 19 listopada 2008 r. w sprawie odpadów oraz uchylająca niektóre dyrektywy, Dz. Urz. UE z 22.11.2008, L. 312, s. 3-30.

Ustawa z dnia 13 września 1996 r. o utrzymaniu czystości i porządku w gminach, Dz. U. z 2017 r. poz. 1289 z późn. zm., tekst jednolity.

Ustawa z dnia 29 stycznia 2004 r. - Prawo zamówień publicznych, Dz. U. z 2017 r. poz. 1579 z późn. zm., tekst jednolity.

Ustawa z dnia 1 lipca 2011 r. o zmianie ustawy o utrzymaniu czystości i porządku w gminach oraz niektórych innych ustaw, Dz. U. z 2011 r. Nr 152, poz. 897.

Ustawa z dnia 3 marca 2000 r. o zmianie ustawy o odpadach oraz o zmianie niektórych ustaw, Dz. U. z 2000 r. Nr 22, poz. 272.

Ustawa z dnia 14 grudnia 2012 r. o odpadach, Dz. U. z 2016 r. poz. 1987, tekst jednolity.

Ustawa z dnia 22 czerwca 2016 r. o zmianie ustawy - Prawo zamówień publicznych oraz niektórych innych ustaw, Dz. U. z 2016 r. poz. 1020.

Rozporządzenie Rady Ministrów z dnia 23 grudnia 1986 r. w sprawie urządzeń zaopatrzenia w wodę i urządzeń kanalizacyjnych oraz opłat za wodę i wprowadzanie ścieków, Dz. U z 1986 r. Nr 47, poz. 234 z późn. zm.

Rozporządzenie Ministra Środowiska z dnia 29 grudnia 2016 r. w sprawie szczegółowego sposobu selektywnego zbierania wybranych frakcji odpadów, Dz. U. z 2017 r. poz. 19.

\section{Orzecznictwo}

Uchwała Sądu Najwyższego z dnia 24 stycznia 1996 r., III CZP 192/95, OSNC 1996, nr 6, poz. 77.

Wyrok Krajowej Izby Odwoławczej z dnia 3 marca 2017 r., KIO 328/17, LEGALIS nr 1580875.

\section{Materiały źródłowe ze stron internetowych}

Ministerstwo Środowiska, Pismo nr DGO-III.070.15.2017.MK z dnia 5 kwietnia 2017 r., http://orka2.sejm.gov.pl/INT8.msf/klucz/658C47EE/\%24FILE/i10708-ol.pdf [dostęp: 5.01.2018 r.].

Ministerstwo Środowiska, ABC Segregacji odpadów, htpps://www.mos.gov.pl/aktualności/szegoly/news/abc-segregacji-odadow/ [dostęp: 20.12.2017 r.]. 
Opinia prawna Urzędu Zamówień Publicznych nt. in-house, Wspótpraca publiczno-publiczna w rozumieniu ustawy Prawo zamówień publicznych, http://odpady.net. pl/2017/06/05/opinia-prawna-uzp-nt-in-in-house/ [dostęp: 9.01.2017 r.].

\section{LiterATURA}

Barczak A., E. Kowalewska, Opłata za gospodarowanie odpadami komunalnymi, „Acta Iuris Stetinensis" 2014, nr 835, s. 32-33.

Barczak A., E. Kowalewska, Opłaty w zakresie gospodarowania odpadami komunalnymi, „Przegląd Podatków Lokalnych i Finansów Samorządowych” 2014, nr 5, s. 20-23.

Barczak A., Model gospodarowania odpadami komunalnymi w Polsce i Niemczech. Analiza prawnoporównawcza, Szczecin 2013.

Bukowski Z., Prawo gospodarki odpadami, Poznań 2014.

Cieślak R., Jak zamówienia in-house usprawnia gospodarkę odpadami, „Gazeta Samorządu i Administracji" 2017, nr 4, s. 17-18.

Draniewicz B., Mała rewolucja śmieciowa w interpretacji Ministerstwa Środowiska, „Prawo i Środowisko" 2017, nr 2, s. 105-112.

Dziadkiewicz B., Zasady gospodarki odpadami komunalnymi. Poradnik ze wzorami dokumentów, Warszawa 2011.

Górnicki E., Dwa światy - dwa modele - jedna optata, „Przegląd Komunalny” 2012, nr 10, s. 56.

Górski M., Organizacja selektywnej zbiórki odpadów, „Przegląd Komunalny” 2012, nr 5, s. 23.

Jendrośka J., J. Jerzmański (red.), Prawo ochrony środowiska dla praktyków, Warszawa 2006.

Michalski P., Nowe zasady selektywnej zbiórki odpadów, „Gazeta Samorządu i Administracji" 2017, nr 6, s. 25-27.

Ofiarska M., Z. Ofiarski, Finansowe podstawy systemu gospodarowania odpadami komunalnymi, [w:] M. Górski, K. Nowacki (red.), Prawne i organizacyjne obowiazki gmin w postępowaniu z odpadami komunalnymi, Wrocław 2012, s. 196-198.

Poniewski F., Zamówienia in-house w gospodarce odpadami, "Gazeta Samorządu i Administracji" 2016, nr 10, s. 11-13.

Radecki W., Ustawa o utrzymaniu czystości i porzadku w gminach z komentarzem, Wrocław 1997.

Radecki W., Ustawa o utrzymaniu czystości i porzadku w gminach. Komentarz, Warszawa 2008.

Radecki W., Utrzymanie czystości i porzadku w gminach. Komentarz, Warszawa 2012.

Radecki W., Utrzymanie czystości i porzadku w gminach. Komentarz, Warszawa 2015.

Radecki W., Utrzymanie czystości i porzadku w gminach. Komentarz, Warszawa 2016. 
Romańczuk I., M. Rzewnicka, Ustawa o utrzymaniu czystości i porządku w gminach. Komentarz, Warszawa 2017.

Waksmańska M., Projekt ramowej dyrektywy o odpadach, „Prawo i Środowisko” 2006, nr 1, s. 10-15.

Wronkowska S., Na czym polega dobra legislacja?, "Przegląd Legislacyjny” 2002, nr 1, s. 9-23.

\section{THE DYNAMISM OF ENVIRONMENTAL PROTECTION LAW AND ITS INTERPRETATION - REMARKS AGAINST THE BACKDROP OF THE LEGAL PROVISIONS OF U.C.P.G.}

\section{Su m m a r y}

The article presents some selected legal problems arising from the amendment of The Act on maintaining cleanliness and order in municipalities. The attention was paid first of all to the changes that entered into force after January 1 , 2017. Doubts concerning the fees in the field of municipal waste management and the term „municipal waste" were also considered.

Key words: interpretation, municipal waste, selective waste collection, in-house orders, fees in the field of municipal waste management

\section{ДИНАМИЗМ ЗАКОНА О ЗАЩИТЕ ОКРУЖАЮЩЕЙ СРЕДЫ И ЕГО ИНТЕРПРЕТАЦИЯ - ЗАМЕЧАНИЯ В ОТНОШЕНИИ ЗАДАЧИ ЮРИДИЧЕСКИХ ПОЛОЖЕНИЙ U.С.P.G.}

\section{Резюме}

В статье представлены некоторые отдельные правовые проблемы, возникающие в связи с поправкой к Закону о сохранении чистоты и порядка в муниципалитетах. Внимание было обращено прежде всего на изменения, которые вступают в силу после 1 января 2017 года. Были также рассмотрены сомнения в отношении сборов в области утилизации муниципальных отходов и термин «муниципальные отходы

Ключевые слова: нтерпретации, муниципальных отходов, выборочного сбора отходов, внутренних заказов, сборов в области управления муниципальными отходами 
